\title{
THE IMPORTANCE OF SOFT SKILLS FOR ACCOUNTING STUDENTS IN MALAYSIA
}

\author{
Suhaiza Ismail
}

\begin{abstract}
This study empirically examines the importance of soft skills for accounting students in Malaysia. Survey questionnaires were distributed to 450 accounting students and practitioners. The total usable response rate for this study is $50.9 \%$. The data were analysed using descriptive statistics including mean score, standard deviation, and ranking based on mean scores. The study found that the top three reasons for the importance of accounting graduates to acquire soft skills are "to provide high quality and professional services', 'to fulfil the expectation of employers' and 'to have better career prospects'. The findings imply that accounting students need to realize the importance of acquiring soft skills and actively equip themselves with soft skills demanded by the profession. The present study contributes to existing literature by offering empirical evidence on the importance of soft skills for future accountants, which is currently scarce.
\end{abstract}

Keywords Soft Skills, Accounting Students, Malaysia

\section{Introduction}

Globalization and innovations in Information Technology require institutions of higher education to produce graduates fluent in both technical knowledge (hard skills) and soft skills. Possessing technical knowledge alone is no longer sufficient for preparing graduates for their future career. Employers now look for employees with a healthy blend of soft and hard skills (Weber et al., 2009; and Villiers, 2010). An employee who is technically competent and equipped with the necessary soft skills, such as communication and thinking skills, benefits the company by delivering better quality services (Bancino and Zevalkink, 2007). Furthermore, Mara et al. (2007) claimed that accountants are expected to combine hard and soft skills to enable them to better multitask in today's modern business environments.

Realizing the fundamental importance of soft skills among graduates, the Malaysian Ministry of Higher Education (MOHE) has emphasized the need for institutions of higher education to expose students to soft skills during their studies and has conducted an online survey on final year undergraduate students to

Corresponding author: Dr Suhaiza Ismail is an Associate Professor at the Department of Accounting, Kulliyah of Economics and Management Sciences, International Islamic University Malaysia, email: suhaiza@iium.edu.my 
determine their level of soft skills among tertiary students in Malaysia. The online survey, known as the Malaysian Soft Skill Scale (My 3s), comprises seven types of soft skills, namely communication, thinking and problem-solving; teamwork; lifelong learning and information management; entrepreneurship; ethics; morality and professionalism; and leadership skills (Aida Suraya, 2005; and Ministry of Higher Education, 2012).

The need for soft skills has been emphasized in several professions, including accounting (Howieson, 2003; Hassall et al., 2005 and 2010, and Johnston and McGregor, 2005). Weber et al. (2009) argued that companies might not be concerned with the technical skills of their entry-level managers because they will be trained according to company standards, but most want their future managers to have soft skills to be successful within the organization. Therefore, apart from providing students with the hard/ technical skills, universities have been entrusted with the task of grooming students with the soft skills required to be successful professionals (Aida Suraya et al., 2005).

There is a paucity of empirical studies on the importance of soft skills for fresh accounting graduates upon joining the profession. The present study empirically examines the importance of soft skills for accounting students. It contributes to existing literature by offering empirical evidence concerning the importance of soft skills for future accountants. The findings may also motivate accounting students to acquire the necessary soft skills by understanding the key reasons why they need to do so. The next section of this paper reviews literature pertaining to the importance of soft skills. This is followed by a discussion of the methodology and research findings. The paper concludes by discussing the implications of the findings, identifying the limitations of the study, and offering suggestions for future research.

\section{Literature review}

Previous studies on the importance of soft skills have been predominantly conceptual and not empirical. To date, the majority of research on soft skills has focused on its various elements (Rumble, 1998; Ahadiat, 2002; and Hassall et al., 2005), exposure to soft skills during the study period (Rumble, 1998; Ahadiat, 1999 and 2002; Hassall et al., 2005; Jackling and Lange, 2009; and Tempone et al., 2012) and effective methods for delivering soft skills (Mintz, 1995; Rumble, 1998; Ballantine and Larres, 2007; and Ameen et al. 2010).

To enhance employability, accountants are expected to have solid accounting and analytical skills, together with other soft skills (Jackling and Lange, 2003; Hairuzila et al., 2009; Sharma, 2009; and Villiers, 2010). This was supported by Penafort and Bedah (1997) who claimed that skills such as an analytical mind, effective communication, leadership, and teamwork for accountants are important to most Malaysian employers. Researchers from Universiti Sains Malaysia also revealed that graduates who lacked soft skills may face difficulty 
obtaining employment (Munir, 2005). Despite this, recent studies by the Ministry of Higher Education (MOHE) on graduate employability from 2006 to 2009 showed a significant improvement in graduate employability. This could have been the result of certain initiatives by MOHE, such as the introduction of a soft skills module to produce graduates who are ready for the workplace (Salina, Nurazariah, Noraina and Jegatheesan, 2011). Therefore, as claimed by Velasco (2012), the selection criteria for candidates must include soft skills, although hard skills and other characteristics are also screening devices to avoid unprofitable candidates.

Graduates are required to have academic knowledge, and the skills that will enhance their prospects for employment (Gammie et al., 2002; Main, 2009; Brungardt, 2009; Chakraborty, 2009; Sharma, 2009; and Balaji and Somashekar, 2009). According to Dhobale (2009), soft skills are necessary for an individual's career enhancement since these skills are personal traits that determine an individual's interaction with others, his communication skills and job performance. Management or supervisory positions also require candidates to demonstrate that they have effective communication, teamwork, and leadership skills (Usoff and Feldmann, 1998; and Bancino and Zevalkink, 2007). Impressive soft skills, for example, are an important reason for promotion (Guinn et al., 2004). Similarly, Balaji and Somashekar (2009) suggested that when a company is faced with downsizing the number of its employees, those with extra skills are often retained.

Accounting professionals and researchers have, for over a decade, advocated changes in the education system to emphasize the introduction of soft skills in the accounting curriculum (Burnett, 2003; Hurt, 2007; Schulz, 2008; and Sugahara et al., 2010). Although the acquisition of technical accounting skills is essential, there is an increasing need for accountants to have greater soft skills (French and Coppage, 2000). The success of institutions of higher learning in preparing graduates with both technical knowledge and soft skills reflects the good image of the university as a provider of human capital for the industry (Hairuzila et al., 2009).

According to Rumble (1998), accountants need additional skills and competencies to provide high quality professional services to clients. This is also supported by Villiers (2010) who claimed that soft skills can be positively linked to strong performance at all levels. In addition to job specific knowledge, it is also important to have additional skills for enhanced performance. An expansion of the roles undertaken by practicing accountants has resulted in increased proficiencies required of accounting graduates (Jones and Abraham, 2007). As claimed by Quek (2005), graduates who have generic skills such as problemsolving and innovation skills are better able to satisfy the demands of complex work situations. Although technical or hard skills will always be a priority for accounting students, soft skills are central to one's ability to survive and compete 
in the dynamic and complex business world (Ng, 2000; French and Coppage, 2000; Kermis and Kermis, 2008; and Tempone et.al., 2012).

In light of the above, soft skills for accounting students are necessary to enhance employability, better career prospects, reflect a good image of the university, earn a better salary, provide high quality professional services, meet employer expectations and to succeed academically. Given its importance, the present study provides empirical evidence supporting what is currently a theoretical premise.

\section{Methodology}

\subsection{Research instrument}

This study collected data through a survey questionnaire comprising two sections. The first section pertains to the demographic information of the respondents, while the second concerns the importance of soft skills. Based on an extensive literature review (Penafort and Bedah, 1997; Rumble, 1998; Gammie et al., 2002; Munir, 2005; Jones and Abraham, 2007; Balaji and Somashekar, 2009; Brungardt, 2009; Chakraborty, 2009; Dhobale, 2009; Main, 2009; and Sharma, 2009) seven factors or reasons for accounting graduates to acquire soft skills were listed in the questionnaire. They were: 'to achieve better academic results'; 'to reflect a good image of the university'; 'to earn a higher salary'; 'to have better career prospects'; 'to fulfil the expectations of employers'; 'to have greater employability'; and 'to provide high quality and professional services'. In rating the importance of each factor, a five-point Likert scale from 1 (not important) to 5 (critically important) was used.

\subsection{Respondents, questionnaire distribution, and response rate}

The survey respondents consisted of accounting students and practitioners. Practitioners were those directly involved in accounting tasks and were, therefore, aware of the significance of soft skills for the profession. Meanwhile, accounting students were those who were soon to join the accounting profession, were expected to have acquired the necessary soft skills during their study programme and were, therefore, expected to acknowledge the importance of soft skills in their future careers. For accounting students, a total of 50 questionnaires were sent to the heads of accounting departments of five public universities for distribution to final year accounting students. As for accounting practitioners, a total of 200 questionnaires were sent to accounting practitioners in companies located in the Klang Valley. Their addresses were obtained from a database of the Malaysian Institute of Accountants. A total of 450 questionnaires were distributed. A cover letter was attached to each questionnaire and contained information on the need for the study and instructions on the survey instrument. Two weeks after the initial mail, follow up mailings were sent to the respondents who did not return the questionnaires. At the end of the study, a total of 167 questionnaires were 
received from students and 66 from practitioners. Of the total 233 questionnaires received, four questionnaires were found to be incomplete and were therefore excluded from the analysis. This meant that the total number of usable responses was 229 , which represented an overall response rate of 50.9 per cent.

\subsection{Data analysis procedure}

The data collected from the respondents were analysed using the SPSS statistical package. The main statistical method used to analyse the findings was descriptive statistics, which included mean, standard deviation, and mean score rankings.

\section{Findings}

\subsection{Demographic profile of respondents}

Table 1 shows the demographic data of the two groups of respondents. Among the respondents who were accounting students, less than three-quarters of them (72.1 per cent) were female; the majority of the student respondents (76.4 per cent) were final year students, while the remaining (23.6 per cent) were third year students.

Table 1: Demographic characteristics of respondents

Panel A: Accounting students $(\mathrm{n}=165)$

\begin{tabular}{llcc}
\hline Demographic Variables & Categories & Frequency & Percentage (\%) \\
\hline 1. Gender & Male & 46 & 27.9 \\
& Female & 119 & 72.1 \\
2.Working Experience & First year & - & - \\
& Second year & - & - \\
& Third year & 39 & 23.6 \\
& Final year & 126 & 76.4 \\
\hline
\end{tabular}

As for the respondents who were practitioners, less than two-thirds of the respondents (64.1 per cent) were female. Most of the respondents were over 36 years of age (28.2 per cent) or between 21 and 25 years ( 28.1 per cent), while more than a quarter of them were between 26 and 30 years ( 26.5 per cent), and less than a fifth between 31 and 35 years ( 17.2 per cent). In addition, the majority of the practitioners (81.3 per cent) held a bachelor's degree in accounting, more than a fifth had professional certificates (12.4 per cent), and less than one tenth (6.3 per cent) had a master's degree. The majority of practitioners had work experience greater than five years (58.5 per cent), and about a third (32.9 per cent) had more than 10 years of relevant accounting experience. Based on the demographic information of the respondents, it was concluded that both the students and practitioners involved in this study were credible participants. 
Panel B: Accounting practitioners $(\mathrm{n}=64)$

\begin{tabular}{llcc}
\hline Demographic Variables & Categories & Frequency & Percentage (\%) \\
\hline 1. Age & 21-25 years & 18 & 28.1 \\
& 26-30 years & 17 & 26.5 \\
& 31-35 years & 11 & 17.2 \\
& 36-40 years & 9 & 14.1 \\
& 41years and above & 9 & 14.1 \\
2. Gender & Male & 23 & 35.9 \\
3 & Female & 41 & 64.1 \\
& Bachelor's degree & 52 & 81.3 \\
& Master's degree & 4 & 6.3 \\
4.Working Experience & Professional certificate & 8 & 12.4 \\
& 1 year or less & 15 & 23.4 \\
& 2 to 5 years & 18 & 28.1 \\
& 6 to 9 years & 10 & 15.6 \\
& 10 years and more & 21 & 32.9 \\
\hline
\end{tabular}

\subsection{Results of the Importance of Soft skills for Accounting Students}

Seven reasons for the need of accounting graduates to acquire soft skills were listed in the questionnaire. Table 2 illustrates the mean scores, standard deviations, and ranking of each reason as perceived by the overall respondents.

Table 2: The Importance of Soft Skills

\begin{tabular}{lccc}
\hline Importance of soft skills & Mean & Std. Dev. & Ranking \\
\hline To provide high quality and professional services & 4.76 & .629 & 1 \\
To fulfil the expectations of employers & 4.39 & .715 & 2 \\
To have better career prospects & 4.26 & .803 & 3 \\
To have greater employability & 4.22 & .685 & 4 \\
To reflect the good image of the university & 3.98 & .683 & 5 \\
To earn a higher salary & 3.36 & .844 & 6 \\
To achieve better academic results & 3.18 & .784 & 7 \\
\hline Bachelor's degree & 52 & & $81.3 \%$ \\
Master's degree & 4 & & $6.3 \%$ \\
Professional certificate & 8 & & $12.4 \%$ \\
\hline
\end{tabular}

Based on the mean scores that range from 3.18 to 4.76, each reason for acquiring soft skills was perceived differently by the respondents in terms of its importance. Of the seven reasons, 'to provide high quality and professional services' was perceived as highly important with a mean score of 4.76 , while four 
reasons on the need for soft skills were rated as 'important', and two reasons were perceived as neither important nor unimportant by the respondents. Based on the ranking, the top three reasons for accounting graduates to acquire soft skills, in descending order of importance are: 'to provide high quality and professional services' $(\mathrm{M}=4.76, \mathrm{SD}=0.629)$; 'to fulfil the expectations of employers' $(\mathrm{M}=4.39$, $\mathrm{SD}=0.715)$; and 'to have better career prospects' $(\mathrm{M}=4.26, \mathrm{SD}=0.803)$. On the other hand, 'to earn a higher salary' ( $\mathrm{M}=3.96, \mathrm{SD}=0.844)$ and 'to achieve better academic results' $(\mathrm{M}=3.78, \mathrm{SD}=0.784)$ were ranked last.

'To provide high quality and professional services' was ranked as the most important reason for accounting graduates to acquire soft skills. This lends support to Rumble (1998) that additional skills and competencies were needed for accountants to deliver greater quality services. When performing the tasks of an accountant, an individual who possesses thinking and problem-solving skills as well as other soft skills in addition to key technical accounting knowledge would be able to perform his professional services better than those who lack such soft skills. For example, a person with good communication skills is able to build a better relationship with clients.

'To fulfil the expectations of employers' was ranked as the second most important reason. This is consistent with Weber et al. (2009) who claimed that contemporary companies were not only concerned with technical knowledge when hiring new employees, as it could be taught and learnt. What was equally important was for future employees to be equipped with appropriate soft skills. Working as an accountant is no longer just about understanding and interpreting accounting standards or preparing financial statements. Instead, businesses these days require cognitive or higher order thinking skills (Penafort and Bedah, 1997; Main, 2009; and Jones and Abraham, 2007).

The third most important reason was to 'have better career prospects'. Career prospects can be seen from two perspectives, the first concerns during times of retrenchment and the second promotion. According to Ted (2000), as quoted by Balaji and Somashekar (2009), when a company is downsizing the number of its employees, those with extra skills are often retained. Similarly, Sharma (2009) stated that soft skills were important for the future progress of one's career. Weber et al. (2009) further claimed that most companies wanted their future managers to have soft skills. In other words, accounting jobs today require individuals who can write and speak well, are able to solve problems, absorb new information quickly and work well with others.

As shown in Table 2, to have 'greater employability' was the fourth ranked reason. As claimed by Chakraborty (2009), soft skills play an important role in making students employable. When competition for fresh graduates to obtain jobs is stiff due to the increasing number of graduates, applicants with better soft skills would have an advantage. As emphasized by Penafort and Bedah (1997), employers in Malaysia are looking for candidates with good soft skills to serve 
as accountants such as those with an analytical mind, or with communication, leadership and teamwork skills.

Of the seven reasons listed, 'to achieve better academic results' and 'to earn a higher salary' were rated as neither important nor unimportant and were ranked as the last two reasons why graduates should acquire soft skills. This result was expected because salaries for accountants at the entry level were often standardised, although it could vary a little from one company to another. In other words, salaries of entry-level accountants seldom differed because of soft skills. In relation 'to achieving better academic results' which was ranked last or perceived as neutral by the respondents, this reflected the current emphasis on technical knowledge. To some extent, it contradicts French and Coppage (2000) who claimed that students entering undergraduate accounting programmes should possess soft skills which could contribute to academic success.

\section{Implications, Limitations, and Suggestions for Future Research}

The present study addresses the lack of empirical evidence on reasons for accounting graduates to acquire soft skills. Questionnaires were distributed to 450 respondents consisting of accounting students and practitioners. The overall usable response rate was 50.9 per cent. Five out of the seven reasons for acquiring soft skills listed in the questionnaire were perceived as either important or highly important. Based on the mean score ranking, the top three reasons for accounting graduates to acquire soft skills, in descending order of importance, were 'to provide high quality and professional services'; 'to fulfil the expectations of employers' and 'to have better career prospects'. 'To earn a higher salary' and 'to achieve better academic results' were reasons perceived to be neither important nor unimportant.

The top three reasons for accounting student to acquire soft skills are mainly related to success in their careers. This might provide information to employers to ensure that potential employees were equipped with soft skills to perform at work. It also meant that employers need not send new employees for soft skills training. The firms' allocation for staff training could therefore be utilized for other training programmes, such as to update employees on new or revisions in accounting standards.

The finding that the acquisition of soft skills was neither important nor unimportant to excel academically reflects on the accounting degree programmes in Malaysia that emphasize technical knowledge when assessing student performance. Soft skills should be made a component of student performance assessments. For enforcement purposes, the relevant authorities such as the MOHE might now want to make assessments of soft skills obligatory in tertiary institutions. Appropriate training should be provided to academics to ensure 
that they are well-equipped to evaluate soft skills performance among students objectively.

This study also shows that soft skills are important for success in the accounting career. To some extent, it implies that soft skills are best developed in the workplace rather than in college. This was because the workplace was where students gained exposure to the accounting profession in terms of dealing with clients, interacting with various groups of people, making necessary decisions and solving real business problems. In other words, soft skills were naturally developed and improved through work experience.

This study is not without its limitations. Due to time and cost constraints, it focused solely on accounting students and practitioners from the Klang Valley. The results, therefore, are inadequate to draw conclusions for accounting students throughout Malaysia. Future studies should use a larger sample to include practitioners and accounting students of public and private universities from various parts of the country. They should also consider involving academics who are involved in developing soft skills among graduates. The use of questionnaires which lack open-ended questions was another limitation of this study. Interviews could be conducted to deepen understanding of the importance of soft skills for future accountants. Despite its limitations, this study offers empirical evidence on the reasons for accounting students to acquire soft skills.

\section{References}

Ahadiat, N. (1999). Skills necessary for a successful career in accounting. Retrieved May 20, 2008. http://www.Newaccountantusa.com/newsfeat/ wealthmanagement/skills. pdf

Aida Suraya Md. Yunus, Rosini Abu, Sharifah Mohd Nor, Rohani Ahmad Tarmizi, Kamariah Abu Bakar, Wan Zah Wan Ali, Ramlah Hamzah \& Habsah Ismail (2005). Generic Skills of Malaysian University Students. Bulletin of Higher Education Research. Instititut Penyelidikan Pendidikan Tinggi Negara, No. 6, 5-6.

Ameen, E., Jackson, C. \& Malgwi, C. (2010). Student perceptions of oral communication requirements in the accounting profession. Global Perspectives on Accounting Education, Vol. 7, 31-49.

Balaji, K.V.A \& Somashekar, P. (2009). A comparative study of soft skills among engineers. The IUP Journal of Soft Skills, Vol.3, No. 3/4, 50-57.

Ballantine, J. \& McCourt Larres, P. (2007). Cooperative learning: a pedagogy to improve students' generic skills?. Education \& Training, Vol. 49, No. 2, 126-137.

Bancino, R. \& Zevalkink, C. (2007). Soft skills: The new curriculum for hard core technical professionals. Retrieved May 28, 2011. http://www.acteonline. org Brungardt, C.J. (2009). College graduates' perceptions of their use of teamwork skills: soft skills development in Fort Hays State University Leadership 
Education. Dissertation Abstracts International, (University Microfilms No. 3389821, 170).

Burnett, S. (2003). The future of accounting education: A regional perspective. Journal of Education for Business, Vol. 78, 129-134.

Chakraborty, M. (2009). Soft skills: Essential for shaping well-rounded individuals. The Icfai University Journal of Soft Skills, Vol. 3, No. 2, 13-18.

Dhobale, R.S. (2009). Stress management training:A boon to employee wellness!. The Icfai University Journal of Soft Skills, Vol. 3, No. 1,39-44.

French, G.R. \& Coppage, R.E. (2000). Educational issues challenging the future of the accounting profession. Ohio CPA Journal, Vol. 59, No. 3, 69-73.

Friedlan, J.M. (1995). The effects of different teaching approaches on students' perceptions of the skills needed for success in accounting courses and by practicing accountants. Issues in Accounting Education, Vol. 10, No.1, 47. Gammie,B., Gammie, E. \& Cargill, E. (2002). Personal skills development in the accounting curriculum. Accounting Education, Vol. 11, No. 1, 63-78.

Guinn, R.E., Bhamornsiri, S. \& Blanthorne, C. (2004). Promotion to partner in big firms: Truths and trends. CPA Journal, Vol. 74, No. 4, 54- 55.

Hairuzila Idrus, Hazadiah Mohd Dahan \& Normah Abdullah (2009). Challenges in the integration of soft skills in teaching technical courses: Lecturers' perspectives. Journal of University Education, Vol. 5, No. 2, 67-81.

Hassall, T., Joyce, J., Montano, L.A. \& Anes, J.A.D. (2005). Priorities for the development of vocational skills in management accountants: A Eropean perspective. Accounting Forum, Vol. 29, 379-394.

Hassall, T., Joyce, J., Montano, J.L.A. \& Gonzalez, J.M.G. (2010). The vocational skill priorities of Malaysian and UK students. Asian Review of Accounting, Vol. 18, No. 1, 20-29.

Howieson, B. (2003). Accounting practice in the new millennium: is accounting education ready to meet the challenge?. The British Accounting Review, Vol. 35, 69-103.

Hurt, B. (2007). Teaching What Matters: A new conception of accounting education. Journal of Education for Business, 295-299.

Jackling, B. \& Lange, P.D. (2009). Do Accounting graduates' skills meet the expectations of employers? A matter of convergence or divergence. Accounting education: an international journal, Vol. 18, No. 4/5, 369-385.

Johnston, S. \& McGregor, H. (2005). Recognizing and supporting a scholarship of practice: Soft skills are hard. Asia Pacific Journal of Cooperative Education, Vol.6, No.1, $1-6$.

Jones, G. \& Abraham, A. (2007). Education implications of the changing role of accountants: Perceptions of practitioners, academics and students. University of Wollongong, Research online. Retrieved May 1, 2011. http:// ro.uow.edu.au/commpapers/296. 
Kermis, G. \& Kermis, M. (2008). Professional presence and soft skills: a role for accounting education. Retrieved September 18, 2011. http://www.aabri. com/manuscripts/09246.pdf

Kohn, A. (2008). Why it's hard to beat, but also hard to find. Retrieved September 29, 2012. http://www. alfiekohn. org/teaching/progressive.htm

Labaree, D.F. (2005). Progressivism, schools and schools of education: An American romance. Pedagogica Historica, Vol. 41, No. 1/2, 275-288.

Main, M. (2009). Transforming accounting education: Addressing the accounting education change commission mandate in practice. Dissertation Abstracts. (University Microfilm No.3344520, 180).

Mara Ridhuan Che Abdul Rahman, Tengku Akbar Tengku Abdullah, Arawati Agus \& Mohd Mohid Rahmat. (2007). Universities - Workplace Competency Gaps: A Feedback from Malaysian Practising Accountants. Journal of Financial Reporting and Accounting, Vol. 5, No.1, 119 - 137

Ministry of Higher Education (2012). Malaysian soft skills scale. Retrieved June 2, 2012. http://jpt.mohe.gov.my/my3s/members/index_home.php

Mintz, S.M. (1995). Virtue ethics and accounting education. Issues in Accounting Education, Vol. 10, No. 2, p. 247.

Munir Shuib (2005). Preparing Graduates for Employment. Bulletin of Higher Education Research, Instititut Penyelidikan Pendidikan Tinggi Negara, $6,1-2$.

$\mathrm{Ng}$, A.Y. (2000). Perceptions of first-line managers in the manufacturing sector on tertiary accounting education: A Hong Kong study. Education Journal, Vol. 28, No. 1, 139-150.

Penafort, F. \& Bedah binti Ahmad (1997). Employers' expectations on today's accounting profession: A Malaysian case- study. Asian Review of Accounting, Vol. 5, No. 2, 78-97.

Quek, A.H. (2005). Learning for the workplace: a case study in graduate employees' generic competencies. Journal of Workplace Learning, Vol. 17, No. 4, 231-242.

Rumble, R.W. (1998). Accounting skills and programs needed for the next century as viewed by colleges and universities. Dissertation Abstracts. (University Microfilm No. 9914572, 152).

Salina Daud, Nurazariah Abidin, Noraina Mazuin Sapuan \& Jegatheesan Rajadurai (2011). Enhancing university business curriculum using an importanceperformance approach: A case study of the business management faculty of a university in Malaysia. International Journal of Educational Management, Vol. 25, No. 6, 545-569.

Schulz, B. (2008). The importance of soft skills: Education beyond academic knowledge. Journal of Language and Communication, 146-154.

Shakir, R. (2009). Soft skills at the Malaysian institutes of higher learning. Asia Pacific Education Review, Vol. 10, 309-315. 